\title{
Torah and prophecy: A debate of changing identities
}

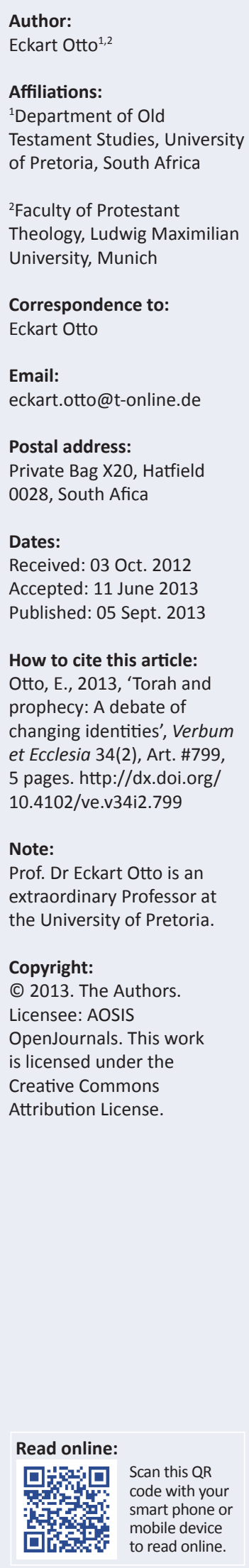

The study interprets the postexilic book of Deuteronomy as a prophetic testament, which characterises Moses as the only arch-prophet (Dt 34). This was a position not of prophetic groups of the Second Temple Period, but of priestly scribes who were responsible for the postexilic redaction of the Pentateuch. They were in a discourse with postexilic groups and schools of prophetic scribes who denied the priestly theory of legitimate prophecy, especially in the book of Jeremiah, but also in Isaiah. The study highlights the discussion and draws some conclusions about postexilic circles of authors in Torah and prophecy.

\section{Introduction}

Old Testament scholarship of the 19th century in Europe was characterised by the debate about the relationship between the Torah and prophecy. Were the prophets since the 8th century BCE preachers of the Torah, which was neglected by the people of Israel and Judah - so the conservative perspective? Or was the Torah derived from prophecy - so the thesis of liberal exegetes, like Julius Wellhausen and Abraham Kuenen ${ }^{1}$ The 20th century saw more literary differentiations on both sides of the Torah and prophecy. The last decades saw a farewell to Wellhausen's documentary hypothesis in favour of models of 'relecture' and redaction, even if some scholars in Israel (see e.g. Schwartz 2009) and North America (see e.g. Stackert 2007 and Baden 2009) are trying a pre-Wellhausen revival with a 'New Documentary Hypothesis', which is only a reprise of the documentary hypothesis of Wellhausen's forerunner, H. Hupfeld (1853). The exegetical research in the prophetic literature was no longer focused on the search for isolated single sayings of an ipsissima vox of prophets as it was until the eighties of the last century, but in the last decades it became more and more aware of the meanings of literary processes of the formation of the prophetic books by relecture and redaction. ${ }^{2}$ This article will concentrate on the postexilic literary history of the final form of the books of Jeremiah and Isaiah, asking what the relation was of these books to the postexilic relectures and redactions of the final Pentateuch, so that all of them could become part of one and the same canon. Although they were counterparts in an intensive postexilic discourse about the question if legitimate divine revelation was mediated by Moses in the past, or if revelation is mediated by prophets in the present and future, each side in this discourse used the same scribal techniques of putting forward their arguments by exegesis of authoritative mosaic or prophetic texts. Odil Hannes Steck (1985:81-99, 1991:270-277), the great German interpreter of the book of Isaiah, spoke of the postexilic relecture and redaction of prophetic books as 'Tradentenprophetie' [prophecy by transmission of texts]. Contemporary to this postexilic scribal prophecy through exegesis of prophetic words, postexilic priestly authors of the Pentateuch interpreted Moses as the arch-prophet and Deuteronomy as his testament (Otto 2012a:258-280). How were these two postexilic perspectives on prophecy interrelated? This is the question of this article. Firstly, we go into the prophetic aspects of the final form of the book of Deuteronomy as the conclusion to the Pentateuch.

\section{The prophetic Deuteronomy as the conclusion of the final Torah}

The prophetic interpretation of the figure of Moses started literary-historically with the deuteronomistic insertion of an announcement of a prophet like Moses in Deuteronomy 18 (cf. Nihan 2010):

YHWH, your God, shall raise up a prophet like me from your midst, from your brothers; you shall listen to him, just as you requested YHWH your God at Horeb, on the day of assembly, saying: I cannot continue to listen to the voice of YHWH my God, nor can I look at the great fire again, so that I will not die. And YHWH said to me: They are right in what they have said. I will raise up a prophet for them, from the midst of their brethren, just like you; and I will put my word in his mouth and he shall tell them all that I command him. (Dt 18:15-18)

1.For these 19 th century debates cf. Otto (2012a:73-105).

2.It was the cutting-edge Ezekiel-commentary by Walther Zimmerli (1969) that opened up new dimensions for the German and international exegetical interpretation of prophetic books. 
This was already the expectation of the authors of the deuteronomistic Deuteronomy in the 6th century in the exilic period. In the postexilic period of the 4 th and 5 th centuries, Deuteronomy became more and more a book completed by prophetic motives. The prophet Moses became an archprophet, because there would never again be a prophet like Moses in Deuteronomy 34 (cf. Nihan 2010):

And a prophet like Moses did not rise again in Israel, one whom YHWH knew face to face, none like him for all the signs and the wonders which YHWH sent him to do in the land of Egypt, against pharaoh and against all his servants and against all his land; and none like him for all his mighty power and all the great awesome deeds which Moses did in the sight of all Israel. (Dt $34: 10-12)$

In the light of this epitaph of the Pentateuch, Moses acted in the postexilic relecture of the frame of Deuteronomy as prophet announcing the catastrophe of Israel and deliverance of a rest in future in Deuteronomy 4 (cf. Otto 2012a:518-592):

When you bear children and grandchildren and you grow old in the land, and you act perversely and make an image, the form of anything, and you do wrong in the eyes of $\mathrm{YHWH}$ your God, provoking him to anger, then I summon heaven and earth as witness against you today, that you shall certainly perish quickly from the land, toward which you are about to cross the Jordan in order to take possession of it; you will not live long in it, for you will certainly be annihilated. And YHWH will scatter you among the peoples, and you will only survive few in number, among the nations to which YHWH will lead you. And there you will serve gods, the fabrication of human hands, consisting of wood and stone that do not see and do not hear and do not eat and do not smell. And from there you will seek YHWH your God, and you will find him if you seek him with all your mind and all your desire, when you are in distress. And all these things will happen in the days to come, then you will return to $\mathrm{YHWH}$ your God and you will hear his voice. For YHWH is a compassionate God: He will not fail you and he will not destroy you, and he will not forget the covenant of your fathers, which he swore to them by oath. (Dt 4:25-31)

In Deuteronomy 29 and 30, Moses takes up this prophecy of doom in exile and deliverance of a rest (cf. Ehrenreich 2010:71-210):

Then the later generations, your sons, who rise up after you, and the foreigners who come from distant land, will see the calamities that have fallen on the land and the diseases with which YHWH has afflicted it. The whole land will be a burning waste of salt and sulphur, nothing planted, nothing spouting, no vegetation growing on it. It will be like Sodom and Gomorra, Adma and Zeboim, which YHWH overthrew in fierce anger. All the nations will ask: Why has YHWH done this to the land? What is the reason for the burning of his great anger? And the answer will be: It is because this people abandoned the covenant of $\mathrm{YHWH}$, the God of their fathers, the covenant he made with them, when he brought them out of Egypt. They went and served other gods and bowed down to them, gods they did not know, gods he had not given them. Therefore YHWH's anger burned against this land, so that he brought on it all the curses written in this book, and JHWH plucked them off the ground in anger, and in wrath, and in great fury, and he threw them to another land as it is today.

The secret things belong to $\mathrm{YHWH}$, but the things revealed belong to us and our children for ever, so we might do all the words of this Torah. And it will be that when these things come upon you, the blessings and the curses which I set before you and you shall take them to heart wherever you are among all the nations, to which $\mathrm{YHWH}$ your God banished you, and when you and your children return to $\mathrm{YHWH}$ your God and obey him with all your heart and with all your soul according to everything I promulgated to you today, then $\mathrm{YHWH}$, your God will restore your fortunes and have compassion on you and gather you again from all the nations where he scattered you. Even if you have been banished to the most distant countries und the heavens, from there YHWH your God will gather you and bring you back. YHWH your God will bring you into the land, your fathers possessed, and you will take possession of it. He will make you more prosperous and numerous than your fathers. YHWH your God will circumcise your heart and the hearts of your offspring, to enable you to love YHWH your God with all your heart and with all your soul so that you might live. Then $\mathrm{YHWH}$ your God will put all these curses upon your enemies, and upon those who hate you and pursue you. You will again obey YHWH and follow all his commandments, which I am promulgating to you today. And $\mathrm{YHWH}$ your God will grant you abundance of prosperity in all your undertakings, in the fruit of your womb, and in the fruit of your animals, and the fruit of your ground; for YHWH will again rejoice over you and make you prosperous, just as he rejoiced over your fathers, when you will listen to the voice of YHWH your God, keeping his commandments and his statues, which are written in the book of this Torah and return to $\mathrm{YHWH}$ your God with all your heart and with all your soul. (Dt 29:21-30:10)

These prophecies of Moses presuppose the end of exile and they are part of the postexilic revision of the book of Deuteronomy by the postexilic redactions of the Pentateuch. They do not only form a framework for Deuteronomy, but the prophecy in Deuteronomy 4 is also a kind of subtext of allusions for Deuteronomy 5-11 (so also Dt 8:16; 9:26-27; 10:10 and 11:8-9 in connection with Dt 10:12-14). Deuteronomy 5 is reinterpreted by Deuteronomy 4 , and in this connection Moses' prophecy in chapter 4 is an application of Moses' narrative of the Molten Calf in Deuteronomy 9-10. His prophetic function of intercession and role as a righteous sufferer for the people (Dt 1:37 and 3:27) allude to Israel's future of exile and salvation of a rest from exile. In Deuteronomy 31:16-18, YHWH begins to speak and confirms Moses' prophecies of doom in chapters 4, 29 and 30 , but not the prophecies of salvation. It is the revelation of Moses' song in Deuteronomy 32:1-43, with its allusions to psalms, wisdom-literature and the corpus propheticum, that paradoxically confirms the prophecy of salvation - although the song was given as a witness against Israel (Otto 2012b). So at its end, Deuteronomy and all the Pentateuch are opened to a canonical theology: the canon itself, in the function of God's voice, confirms Moses' prophecies of Israel's deliverance in Deuteronomy 4 and chapters 29-30, comparable to YHWH's confirmation of Moses' prophecies of doom in Deuteronomy 31:16-18.

The function of Moses' prophecies in Deuteronomy is misunderstood if it is interpreted as a function of its parenesis. It is just the other way round: the parenesis in the final form of Deuteronomy is related to the prophetic motives in this book. The postexilic authors of the final Deuteronomy addressed it 
to an audience that had survived the catastrophe of the exilic period and that was delivered - waiting for and expecting the final completion of history by the divine circumcision of their hearts (Dt 30:6). In this period (zwischen den Zeiten) they were in danger, according to the postexilic authors of the final Deuteronomy, of failing again by disobedience and losing their divine perfection by the circumcision of their hearts.

Deuteronomy is, so to say, a prophetic book, but it is at the same time a deeply anti-prophetic book. It is this paradox that must be understood if we are to interpret this book. As Deuteronomy 34:10-12 states, Moses as the arch-prophet was the only prophet YHWH ever knew face-to-face, and after Moses no prophet like him have risen in Israel. Deuteronomy 18, verses 15 and 18, seem to contradict Deuteronomy 34:10 and in a diachronical perspective it does. But the literary critical knife does not really help (Otto 2007a), because at the end these are part of one and the same book, which means that the final authors of the book of Deuteronomy saw more than just a contradiction between these two verses. On the contrary, we are to read Deuteronomy 18's verses 15 and 18 against the horizon of Deuteronomy 34:10-12, and vice versa. The prophet who is announced in Deuteronomy 18:18 is not identical to the arch-prophet Moses in Deuteronomy 34:10-12, whom God knew face-to-face, but will only be a prophet like Moses. This means that he will do what Moses did, preaching for application by interpreting the Torah. In the final Deuteronomy Moses interpreted the Sinai-Torah as an application for the people living in the promised land. ${ }^{4}$ This became the perspective of the canon formation connecting the Pentateuch with the corpus propheticum interpreting the prophets as preachers of the Mosaic Torah. This was exactly the counter-position to the postexilic Tradentenprophetie.

\section{Revelation in the Torah and the postexilic book of Jeremiah}

The Pentateuch includes a complex theory of its own literary origins and literary developments (Otto 2012a:258-274). This also is true for the book of Jeremiah, as demonstrated by Jeremiah 36 . The transcription-notices in Jeremiah 36, verses 1, 9 and 32, hint at a complicated literary history behind this book. These transcription notices (which can also be compared with those in Jr 29:1; 30:1-2 in relation to Jr $32: 1 ; 51: 64$ ) have the same function as this kind of notices in the Pentateuch. These Pentateuchal notices differentiating between the transcription by YHWH and Moses at Mount Sinai and Moab are part of a classification system with regard to the legal authority of different collections of legal sentences. The transcription notices in the book of Jeremiah also formed a system of differentiating levels of authority of prophetic words within the book (Otto 2007b:171-184). The 'book of consolation' (Trostbüchlein) in Jeremiah 30-31, which should be written during the period of Zedekiah's reign so the literary theory of the book of Jeremiah itself, was to have a higher authority than the sentences of the prophet,

4.See the Decalogue in Deuteronomy 5 in comparison with the Decalogue in Exodus 20; cf. Otto (2012a:270-272, 699-704). which were recorded by an anonymous author during the reign of Jehoiakim. The authors of the book of Jeremiah used the same techniques for differentiating hermeneutically with regard to the authority of sayings within their works, and also the same techniques of exegesis of authoritative texts as the authors of the Pentateuch. Jeremiah 36:3 quotes Jeremiah 26:3 and Exodus 34:9, which is connected with the 'formula of grace' in Exodus 34:6-8 (Knobloch 2009:171-184). So these authors put Moses' words into Jeremiah's mouth as transcribed by Baruch. Exodus 34:9 enhances the lexeme $n h m$ in Exodus 32:12-14 by the lexeme sl. Exodus 32:12, and especially verse 14 , is taken up from Jeremiah $26: 3$ to be quoted again in Jeremiah 36:3. Exodus 34:9 is linked to the covenant motif in Exodus 34:10. The final remark in Jeremiah 31:34 quotes Exodus 34:9 and hints at Jeremiah 36:3. The complex system of links between Jeremiah 26, 31 and 36 were structured by the reception of the final Sinai pericope in these chapters, conflating texts from different fields of literature using techniques that the priestly scribes also used for the formation of the Pentateuch conflating D and P.

But the authors of the postexilic Tradentenprophetie in the book of Jeremiah and the priestly authors of the postexilic Pentateuch, who were so similar in their use of literary techniques, were entirely different in their hermeneutics and theologies as for the divine revelation. The authors of the Jeremianic Tradentenprophetie did not quote the Sinai pericope in order to confer Moses' authority on Jeremiah, as some scholars are assuming. On the contrary, Jeremiah 31:31-34 especially contradicts this assumption. The authors of Jeremiah 31 rather formed a direct counter-position to the hermeneutics of the Pentateuch represented by the motif of Moses as arch-prophet in Deuteronomy 34:10-12. In Jeremiah 31:31-34, the Pentateuchal theory of a transcription of the Torah by Moses in Exodus 24:4 and Deuteronomy 31:9 was refuted by the prophetic theory of a divine transcription of the Torah on the people's hearts. The Pentateuchal ideas of teaching and learning the Mosaic Torah (Dt 6:6-7, 20-25; $11: 18-21 ; 31: 12-13)$ were refuted by the prophetic motif that there would no longer be any necessity for teaching and learning of the Torah, because it would be internalised by all the people. Also, the Pentateuchal idea of a Mosaic covenant at Sinai and Horeb as the only covenants was overcome by the idea that there would be a new covenant. Following this perspective of a critical reception of the Pentateuch, the authors of Jeremiah 36 put Mosaic words into Jeremiah's mouth, declaring them to be God's own words, ${ }^{5}$ so in Jeremiah 36:4: 'Baruch wrote upon the scroll all the words Jeremiah had dictated that YHWH had spoken to him.' For these prophetic authors of the book of Jeremiah, the divine revelation did not come to an end with Moses' death, but went on even after the Babylonians' destruction of the temple in Jerusalem. For the priestly authors of the postexilic Pentateuch on the other hand, the time of divine revelation has ended with Moses' death, so that the only access to the

5.The same was done two centuries later by the authors of the Temple Scroll: putting Mosaic words of Deuteronomy back into God's mouth, which was here, as in the book of Jeremiah, a form of protest against priestly scribes in Jerusalem who book of Jeremiah, a form of protest against priestly scribes in Jerusalem who
were responsible for the postexilic Fortschreibungen of the Pentateuch and its hermeneutics (cf. Otto 2011:59-64). 
divine revelation could be by interpreting the transcriptions of the revelation in the Mosaic Torah, with Moses as the prototype of a scribal interpreter of the Torah as the first Schriftgelehrter interpreting the Sinai-revelation in the book of Deuteronomy.

\section{The book of Isaiah and the Torah}

The attitude of the postexilic Tradentenprophetie of the Jeremiah school toward the Torah was more critical than those of schools that were responsible for the books of Isaiah and Ezekiel. Benjamin D. Sommer (1998:132-151) demonstrated the intensive reception of the Torah in the book of Isaiah. In Isaiah 40-66 he also observed a kind of reception, which he calls polemically contesting ideas of the Pentateuch, especially those of P. So, Isaiah 56 and 66 have less restrictive feelings toward the access to the altar than $\mathrm{P}$ and abrogate numbers 18 regarding the status of foreigners in the cult. The authors of Isaiah 40-66 tried to correct some aspects of the priestly ideology. As Sommer observed, polemics occur in Isaiah only in the allusions to Pentateuchal texts, but not to other prophetic texts or psalms. But even where the attitude to the Torah was polemical, the authors did not say that it was wrong - only that the situation had changed compared to that of the Torah (Sommer ibid). These polemics represent also, so Sommer, only a minority amongst the many positive typological receptions of the Torah in this book. The history of the Torah was rather used as the basis for prophecy: what occurred in Moses' days will occur again if the behaviour of the people warrants it.

There seems to be more than just a kind of typological structuring of thinking behind the receptions of Pentateuchal texts in the book of Isaiah, as Sommer is suggesting. Ronald Clements (2007:59-72) could demonstrate that there exists a postexilic Torah-redaction in Isaiah, recognisable by the postexilic connotation of the lexeme of the Torah in Isaiah $1: 10 ; 2: 3 ; 5: 24 ; 8: 16$ and $20 ; 24: 5$ and $30: 9$. This redaction is linked to motifs of divine sovereignty over the nations. As Clements (ibid) puts it:

Warnings of coming judgement on the world of nations occasioned the need for setting them in a larger context concerning the nature and purpose of God. This is achieved by introducing in chs. 1-4 the message that all prophecy must be read against a background of torah. Israel had not been judged already and sentenced to an inevitable doom, since the message of torah offered the possibility of life through obedience and loyalty. (p. 69)

There is a decisive difference between the postexilic Tradentenprophetie in the books of Jeremiah and Isaiah. For the postexilic authors of Jeremiah 31:31-32, covenant and the Torah were thought to be no longer valid because of the permanent disobedience of the people since the Exodus out of Egypt (Schenker 2006:20-25). But there will be, so the expectation in the book of Jeremiah, a new covenant and a new Torah, written on the hearts by YHWH. For postexilic authors in the book of Isaiah, YHWH announces doom for the nations, but opens a way for his people to be preserved from doom by the obedience to the Torah, because the covenant is still valid. Although it was permanently violated by the people, it is not yet broken up by $\mathrm{YHWH}$ :

According to what they have done, so will he repay wrath to his enemies and retribution to his foes. He will repay the islands their due. From the west, men will fear the name of YHWH and from the rising of the sun they will revere his glory: For he will come like a pent-up flood, that the breath of YHWH drives along. The redeemer will come to Zion, to those who repent their sins, says JHWH. As for me, this is my covenant with them, says YHWH. (Is 59:18-21)

\section{Conclusion}

This position of the book of Isaiah is much closer to that of the authors of the postexilic Pentateuch than that of the book of Jeremiah. Also, Moses, the prophet in the postexilic Fortschreibung of the Torah, expected and announced that the people would break the Torah and YHWH would intervene, so that there would be doom and annihilation for them in the future, but also deliverance, salvation and, at the end, the circumcision of their hearts after they have returned to YHWH. This is not far away from Isaiah. But there is one difference, and this difference is decisive: all this was already predicted by Moses, so the authors of the Pentateuch, so that no other prophet was needed any more, and if prophets like Isaiah came up, then they were prophets who were doing what Moses had done, preaching the application of the Mosaic Torah (according to Dt 18:18). The prophetic schools, on the other hand, insisted that there would be new divine revelations and new interferences by $\mathrm{YHWH}$, because these scribes of the postexilic Tradentenprophetie were convinced that there was a need for a new divine intervention in history. They did not believe that everything was already done by God and everything was already said by Moses, but they waited for redemption of Israel and the world.

\section{Acknowledgements Competing interests}

The author declares that he has no financial or personal relationship(s) that may have inappropriately influenced him in writing this article.

\section{References}

Baden, J.S., 2009, J, E, and the redaction of the Pentateuch, Mohr Siebeck, Tübingen. (Forschungen zum Alten Testament 68).

Clements, R., 2007, 'The meaning of torah in Isaiah 1-39', in J.G. McConville \& K. Möller (eds.), Reading the Law. Studies in honour of Gordon J. Wenham, pp. 5972, T\&T Clark, London. (Library of Hebrew Bible / Old Testament Studies 461).

Ehrenreich, E., 2010, Wähle das Leben! Deuteronomium 30 als hermeneutischer Schlüssel zur Tora, Harrassowitz, Wiesbaden. (Beheifte zur Zeitschrift für die alttestamentliche Wissenschaft 14).

Hupfeld, H., 1853, Die Quellen der Genesis und die Art ihrer Zusammensetzung, Wiegandt und Greiben, Berlin.

Knobloch, H., 2009, Die nachexilische Prophetentheorie des Jeremiabuches, Harrassowitz, Wiesbaden. (Beheifte zur Zeitschrift für die alttestamentliche Wissenschaft 12).

Nihan, C., 2010, 'Moses and the Prophets: Deuteronomy 18 and the emergence of the Pentateuch as Torah', Svensk exegetisk årsbok 75, 21-55.

Otto, E., 2007a, 'A hidden truth behind the text or the truth of the text at a turning point in Biblical Scholarship two hundred years after De Wette's Dissertatio Critico-exegetica', in J. le Roux \& E. Otto (eds.), South African perspectives on the Pentateuch between synchrony and diachrony, pp. 19-28, T\&T Clark, London. (Library of Hebrew Bible / Old Testament Studies 463). 
Otto, E., 2007b, 'Scribal scholarship in the formation of Torah and prophets. A postexilic scribal debate between priestly scholarship and literary prophecy - the example
of the book of Jeremiah and its relation to the pentateuch', in G.N. Knoppers \& of the book of Jeremiah and its relation to the pentateuch', in G.N. Knoppers \&
B.M. Levinson (eds.), The Pentateuch as Torah. new models for understanding its B.M. Levinson (eds.), The Pentateuch as Torah. new models for underst
promulgation and acceptance, pp. 171-184, Eisenbrauns, Winona Lake.

Otto, E., 2011, 'Tempel scroll and Pentateuch. A priestly debate about the interpretation of the Torah', in K. de Troyer \& A. Lange (eds.), The Qumran legal texts between the Hebrew Bible and its interpretation, pp. 59-74, Peeters, Leuven. (Contributions to Biblical Exegesis and Theology 61).

Otto, E., 2012a, Deuteronomium 1-11, vol. 2, Herder, Freiburg. (Herders Theologischer Kommentar zum Alten Testament).

Otto, E., 2012b, '“Singing Moses”. His farewell song in Deuteronomy 32', in D. Human (ed.), Psalmody and prophecy in Old Testament ethics, pp. 170-180, T\&T Clark, London. (Library of Hebrew Bible / Old Testament Studies forthcoming).

Schenker, A., 2006, Das Neue am neuen Bund und das Alte am alten. Jer 31 in der hebräischen und griechischen Bibel, Vandenhoeck \& Ruprecht, Göttingen. (Library of Hebrew Bible / Old Testament Studies 212).
Schwartz, B.J., 2009, 'Introduction: The strata of the priestly writings and the revised relative dating of $\mathrm{P}$ and $\mathrm{H}^{\prime}$, in $\mathrm{S}$. Shectman \& J.S. Baden (ed.), The strata of the priestly writings. Contemporary debate and future directions, pp. 1-12, TVZ, Zürich. (Abhnadlungen zur Theologie des Alten und Neuen Testament 95).

Sommer, B.D., 1998, A prophet reads scripture. Allusion in Isaiah 40-66, University Press, Stanford.

Stackert, J., 2007, Rewriting the Torah, Mohr Siebeck, Tübingen. (Forschungen zum Alten Testament 52).

Steck, O.H., 1985, Bereitete Heimkehr: Jesaja 35 als redaktionelle Brücke zwischen dem Ersten und dem Zweiten Jesaja, Katholisches Bibelwerk, Stuttgart. (Stuttgarter Bibelstudien 121)

Steck, O.H., 1991, Studien zu Tritojesaja, De Gruyter, Berlin. (Beihefte zur Zeitschrift für die Alttestamentliche Wissenschaft 203).

Zimmerli, W., 1969, Ezechiel, vol. 2, Neukirchener Verlag, Neukirchen-Vluyn. (Biblischer Kommentar XIII). 